\title{
TYÖVÄENHISTORIAN MAHDOLLISUUKSIA JA HAASTEITA 2020-LUVULLA
}

\author{
Anu Lahtinen \\ professori (ma.), Helsingin yliopisto
}

\section{Paljon polkuja, monia suuntia}

Suomessa 2010-luvulla ilmestyneiden, työväenhistoriaan liittyvien nimekkeiden kirjo on laaja. On järjestö- ja liittohistorioita, ruohonjuuritason ja valtakunnan poliitikkojen elämäkertoja, arjen historiaa, kansainvälistä vertailua, nais- ja sukupuolihistoriaa sekä erilaisten tutkimussuuntien kuten taloushistorian tai kulttuurihistorian piirissä valmistuneita tutkimuksia. Opinnäytetyöt, jotka yhä useammin ovat avoimesti verkossa, valaisevat usein kiinnostavasti paikallisia työväenliikkeen ilmiöitä ja toimintaoloja.

Näyttää siltä, että työväenhistoria laajenee moniin suuntiin, ja arkea ja moniäänistä historiaa korostavat näkökulmat avaavat mahdollisuuksia uusiin tulkintoihin. Poliittisen kentän muuttuvat valtasuhteet ovat tukeneet myös menneisyyden tarkastelemista uusista näkökulmista. On ollut kiinnostavaa seurata, miten tutkimus on tuonut uutta valoa työväenliikkeen varhaisten toimijoiden maailmankatsomuksiin ja uskonnollisiinkin vakaumuksiin. Sukupuolen, perheen ja arjen tutkimusta ei ole vielä mitenkään tyhjennetty. Oletettavaa on, että globaali keskusteluyhteys käy yhä merkittävämmäksi. Samalla myös paikallisen on saatava arvonsa niin tiedon kuin identiteettityön lähteenä, ja erilaisten vähemmistöjen asema on myös kasvava mielenkiinnon kohde.

Koska yleinen mielenkiinto historiaan jäsentyy usein merkkivuosien ympärille, voi monipuolisen 1918-muistovuoden jälkeen pohtia, mitä näkymiä 2020-luku tässä mielessä tarjoaa. Suomen tasavallan alkutaipaleen kireät poliittiset suhteet ja työtaistelut voisivat tarjota kiinnostavia vuosipäiviä tarkasteltaviksi, ja tutkimus voisi tarjota kiinnostavia puheenvuoroja nykypäivänkin tilanteeseen. Repivän vuoden 1918 jälkeinen surutyö ja rakentaminen ansaitsisivat myös lisähuomiota. 1920-luvun kansainväliset työväen kohtaamiset sopisivat myös luontevasti tutkimusaiheiksi.

Aika sekä työskentelee tutkijan puolesta että häntä vastaan. Yhtäältä uusia, aiemmin suljettuja aineistoja avautuu, digitoidaan ja järjestetään. Samoin julkaistaan uutta tutkimusta, johon voi tukeutua tai ottaa kriittistä etäisyyttä. Toisaalta aineistoa ja muistitietoa myös häviää, ennen kuin sen arvoa ehditään 
tunnistaa. Eteemme kehkeytyvä nykyhetki muuttaa sitä, mitä menneisyydestä halutaan tietää. Millaisista lähteistä nousee esiin vaikkapa 2000-luvun prekariaatin elämä ja toiminta?

\section{Työtä tulevaisuuden historian puolesta}

Vuosikymmenen vaihtuessa tarjolla on yhä enemmän sekä digitoituja että sähkösyntyisiä aineistoja. Tämä on monella tapaa erinomainen suunta, jonka riskeistäkin on silti hyvä olla selvillä. Aineistot, jotka on digitoitu helposti saataville, saavat enemmän huomiota, ja niihin palataan helpommin. Aineistot, joita ei ole digitoitu, saattavat jäädä unohduksiin. On tärkeää, että digitoidaan ja tuodaan näkyviin aineistoja, jotka tuovat monipuolisesti esiin työväenhistorian kannalta olennaista tietoa. Tässä mielessä esimerkiksi Työväen Arkiston laajat digitaaliset 1918-aineistot ja Työväen historian ja perinteen tutkimuksen seuran aktiivinen verkkojulkaiseminen tuovat aineistoa ja tutkimusta aivan elintärkeällä tavalla näkyville.

Entä uusimman ajan tapahtumien dokumentointi? Vakiintuneiden järjestöjen ja organisaatioiden tuottamat asiakirjalähteet tallentunevat vakiintuneiden arkistointiperiaatteiden mukaisesti. Uusien aineistojen sähkösyntyisyyteen liittyvät toki omat riskinsä - tutkijat ovat todenneet uusimpien pöytäkirjojen hävinneen, kun dokumentit ovat liikkuneet sähköisinä ja koneet ovat vaihtuneet.

Oma kysymyksensä on, miten tallentuu digitaalinen arki, epävarmoissa työoloissa ponnistelevan prekariaatin elämä tai muuntuvainen ruohonjuuritason aktivismi. Miten tallentuu, vai tallentuuko, esimerkiksi sosiaalisen median satunnaisten kontaktien kautta syntynyt toiminta?

Viimeaikaiset tiedonhallintalain linjaukset sekä EU:n tietosuoja-asetus ja sen kotimaiset sovellukset ovat viitanneet siihen suuntaan, että arkeen ja ruohonjuuritasoon liittyvät, henkilötason tietoja sisältävät aineistot saattavat jatkossa seuloutua helpommin pois. Tietosuoja-asetuksen osalta muistiorganisaatiot, arkistot ja tutkijat ovat käyneet paljon keskustelua siitä, miten painottaa ihmisten oikeutta tulla muistetuksi (esimerkiksi työväenliikkeen ruohonjuuritason toimijana) ja miten painottaa tietosuojan korostamaa oikeutta tulla unohdetuksi. Elossa olevien henkilöiden poliittiseen vakaumukseen liittyvä tieto ja toiminta voi olla yhtäältä arvokasta tutkimustietoa ja toisaalta tarkkaan varjeltavaa, tietosuojaa nauttiva tietoa, jonka säilyminen jälkipolville ei olekaan selvää.

Tiedonhallintalain ja päivittämistä odottavan arkistolain osalta taas herää kysymyksiä siitä, millaisia lähteitä jatkossa ohjeistetaan säilytettäväksi. Kuten professori Kirsi VainioKorhonen on huomauttanut, säilyttämisen arvoista "kansalliseen kulttuuriperintöön lukeutuvaa asiakirja-aineistoa" on lakivalmistelussa välillä määritelty tai rajattu kovin kapeasti. ${ }^{1}$ Tällaiset linjaukset voivat olla ongelma, jos arkistointi keskittyy entistäkin enemmän ylätaso- tai jopa yhteenvetodokumentteihin eikä ota huomioon yksilötason merkitystä tutkimuksen kohteena.

Edellä kuvatussa tilanteessa Työväen historian ja perinteen tutkimuksen seuran julkaisutoiminta sekä arkistojen ja aineistokeruiden merkitys ja oma-aloitteisuus pysyvät tärkeinä. Edelleen tarvitaan varmasti suunnitelmallista arkistointia ja lähteiden kokoamista, ja siihen perustuvaa tutkimusta. 2010-luvulla ilmestyneiden nimekkeiden valossa ensi vuosikymmeneltäkin voi odottaa monipuolisia tutkimusavauksia, ja samalla tarvitaan kokoelmatyötä tulevaisuuden historian ja historian tulevaisuuden hyväksi.

1 Vainio-Korhonen, Kirsi 2018. Onko uusi tiedonhallintalaki uhka humanistiselle tutkimukselle? Lastuja Suomen historiasta, Turun yliopiston Suomen historian blogi, 28.9.2018. https://blogit.utu.fi/ suomenhistoria/onko-uusi-tiedonhallintalaki-uhkahumanistiselle-tutkimukselle/ (viitattu 1.8.2019). 